\title{
DUKUNGAN SOSIAL DAN PERILAKU PROSOSIAL DIMEDIASI OLEH EMPATI PADA SISWA
}

\author{
Lilik Mufidah*, Iswinarti, Rr. Siti Suminarti Fasikhah
}

${ }^{\star}$ Corresponding Author:

Magister Psikologi

Universitas Muhammadyah Malang

Email:

Yuklik2727@gmail.com

\begin{abstract}
Abstrak. Kepekaan siswa pada sesama belakangan ini mulai menurun, remaja kurang perduli dengan lingkungan, dan orang lain, tentunya hal ini kurang baik bagi perkembangan remaja itu sendiri,maka dengan ditumbuhkan empati dapat meningkatkan perilaku prososial. Dukungan sosial sangat berperan penting dan punya efek yang kuat pada perilaku prososial. Subjek dari penelitian ini adalah siswa Sekolah Menengah Pertama ( SMP) dengan berjumlah 265 orang. Teknik sampling yang digunakan adalah purposive samping. Perilaku prososial diukur dengan menggunakan skala Prosocial Tendencies Measure-Revised (PTMR). Empati diukur menggunakan Emphaty Questionnaire, dukungan sosial di ukur dengan menggunakan skala Child and Adolescent Social Support (CASS). Analisa data yang digunakan dalam penelitian ini adalah analisis Hayes. Hasil penelitian menunjukan ada hubungan yang signifikan antara dukungan sosial dan perilaku prososial yang dimediasi oleh empati pada siswa. Dapat disimpulkan bahwa dukungan sosial memiliki hubungan terhadap perilaku prososial melalui empati, jadi terbentuknya perilaku sosial karena empati.
\end{abstract}

Kata kunci: Perilaku Prososial, Dukungan Sosial, Empati

\begin{abstract}
Student sensitivity to peers has recently begun to decline, adolescents are less concerned with the environment, and others, of course this is not good for the development of adolescents themselves, so by growing empathy can increase prosocial behavior. Social support is very important and has an important role strong effect on prosocial behavior. The subjects of this study were 265 junior high school students. The sampling technique used was purposive sampling. Prosocial behavior was measured using the Prosocial Tendencies Measure-Revised (PTMR) scale. Empathy is measured using the Emphaty Questionnaire, social support is measured using the child and adolescent social support (CASS) scale. Analysis of the data used in this study is Hayes analysis. The results showed there was a significant relationship between social support and prosocial behavior mediated by empathy for students. It can be concluded that social support has a relationship to prosocial behavior through empathy, so social behavior is formed because of empathy.
\end{abstract}

Keywords: Prosocial Behavior; Social Support; Empathy

\section{PENDAHULUAN}

Perilaku prososial penting ditumbuhkan pada semua individu, terutama pada remaja, tidak hanya terkait dengan pembentukan tanggung jawab sosial dan perilaku moral tapi juga untuk pengembangan, kemajuan, harmoni dan stabilitas masyarakat. Pada era sekarang ini penguatan perilaku prososial siswa telah menjadi fokus pada dunia pendidikan, perila- $\mathrm{ku}$ prososial mengacu pada perilaku individu yang secara sadar melakukan upaya yang bermanfaat bagi orang lain dalam masyarakat (Carlo, Hausman, Christiansen, 2003). Perilaku prososial diterapkan pada penguatan pendidikan karakter (PPK) yang merupakan program pendidikan disekolah untuk memperkuat karakter siswa melalui harmonisasi oleh hati (etik dan spritual), olah rasa (estetik), olah pikir 
(literasi dan numerik) dan olah raga (kinestik) sesuai dengan program pendidikan dalam Perpres nomor 87 tahun 2017. Perilaku prososial adalah suatu perilaku yang menguntungkan dan di dalamnya terdapat unsur-unsur kebersamaan, kerjasama, kognitif, dan berpengaruh pada individu dalam berinteraksi sosial (Kartono, 2003).

Perilaku prososial dipengaruhi oleh gaya pengasuhan, kepercayaan, dukungan sosial, karakteristik kognitif, emosi moral, ciri kepribadian serta situasi sosial (Yang, 2006). Perilaku sosial adalah segala bentuk perilaku yang memberikan konsekwensi positif bagi penerima baik dalam bentuk materi, fisik maupun psikologis tapi tidak ada keuntungan bagi pemberi (Dayaksini, 2009).

Afolobi (2014) menyatakan bahwa perilaku prososial adalah tindakan membantu tanpa mengharap imbalan, tindakan itu dilakukan individu semata-mata karena kepuasan, jadi individu yang kepuasan hidupnya tinggi maka tingkat perilaku sosialnya juga tinggi. Perilaku prososial adalah perilaku suka rela yang di sengaja dan menghasilkan manfaat buat orang lain (Lay, Siu, Shek, 2015).

Perilaku prososial sangat penting diterapkan pada seseorang agar tumbuh keperdulian dengan sesama dan menyadari bahwa individu bukanlah makluk tunggal yang mampu hidup sendiri melainkan sebagai makluk sosial yang tergantung pada orang lain dalam mencapai kebahagian hidup (Sears, Fredman, Peplau, 1991). Perilaku prososial dapat dipengaruhi oleh dukungan sosial, disinilah peran guru, teman sebaya dan orang tua sangat di perlukan guru dan sekolah berupaya semaksimal mungkin bagaimana karakter tumbuh pada siswa. Dukungan dari teman sebaya juga sangat berperan karena teman yang baik atau tidak baik juga sangat berpengaruh pada siswa, yang tidak kalah penting adalah dukungan orang tua, karena pendidikan awal anak diperoleh dari lingkungan keluarga.

Dukungan sosial sangat penting dan memiliki efek positif pada motivasi dan prestasi belajar siswa. Cirik (2015) menegaskan hal positif dari penggaruh sosial itu ialah perasaan memiliki, dihargai dalam suatu lingkungan. Dukungan sosial juga dianggap sebagai motivasi yang bisa diberikan pada seseorang yang membutuhkanya, karena dukungan sosial dapat mempengaruhi kesuksesan siswa di sekolah. Siswa yang memperoleh dukungan sosial yang baik dari orang tua, teman dan guru, menunjukan berbagai hasil yang positif dalam bersosialisasi di sekolah dan juga baik pula perilakunya.

Rook (1990) menyatakan bahwa dukungan sosial sebagai salah satu fungsi pertalian sosial yang meng- gambarkan tingkat dan kualitas umun dari hubungan yang akan melindungi individu dari stress karena dukungan yang diterima dapat membuat individu tenang, merasa di perhatikan lalu muncul rasa percaya diri. Tersedianya dukungan sosial akan membuat seseorang merasa dicintai dihargai dan merasa menjadi bagian dari kelompok dan dukungan sosial harus didapat semua individu. Hasil penelitiannya menyatakan bahwa dukungan sosial sangat berdampak pada psikologis siswa, ketika siswa memiliki dukungan sosial yang baik dan memadai dapat mengurangi masalah yang terjadi (Yasin, 2010).

Kemampuan empati mulai tumbuh pada diri seseorang ketika memasuki waktu akhir kanak-kanak tapi bentuk keinginan empati sudah terlihat sejak bayi yaitu adanya respon tangisan bayi ketika mendengar bayi lain menangis. Yang merupakan proses dari aspek non kognitif (Hoffman, 2000). Proses menumbuhkan perilaku empati bisa diberikan oleh keluarga sedini mungkin, dan semua orang mempunyai kemampuan berempati akan tetapi beda cara mengaktualisasikanya. Gordon, Delton, Kolbert, Kanyongo dan Crothers, (2004) mengungkapkan bahwa empati adalah kemampuan seseorang dalam memahami emosi orang lain yang memunculkan sikap perduli pada orang lain dalam bentuk penghargaan. Sedangkan Batson (2010) menyimpulkan empati adalah kepedulian yang dirasakan seseorang, yang mendorong munculnya motivasi untuk membantu dan meringankan beban orang lain dan timbul ketika individu menempatkan dirinya pada kondisi dimana dia yang mengalami peristiwa yang orang lain alami.

Empati merupakan suatu aktivitas untuk memahami apa yang sedang dipikirkan dan dirasakan orang lain tanpa yang bersangkutan kehilangan kontrol diri Taufik (2013) Empati adalah kemampuan individu berdasarkan perasaan, pikiran dan motif untuk mengerti, memahami dan menghargai serta memandang situasi dari perilaku yang diamati pada orang lain (Valente, 2016). Berdasarkan hasil penelitian beberapa tokoh tersebut, disimpulkan empati adalah kemampuan yang dimiliki seseorang dalam menghargai dan memahami keadaan seseorang secara jujur tanpa dibuat- buat .

Menurut Krevan dan Gibbs (1996) bahwa hubungan antara empati dan perilaku prososial sangat berkaitan erat dan saling mempengaruhi dan punya peran penting.Individu yang mempunyai rasa empati adalah orang yang berjiwa sosial, punya keperdulian yang tinggi pada orang yang membutuhkan . Empati berkorelasi positif pada perilaku prososial, empati juga dapat menghilangkan perilaku sosial negatif dan meningkatkan interaksi prososial seseorang pada 
orang lain (George, 2006).

Menurut Lannotti (1978), bahwa empati adalah motif dasar seseorang bertindak prososial. Empati mampu meningkatkan perilaku prososial yang menghasilkan respon pada situasi seseorang, seperti tindakan membantu serta peduli pada yang membutuhkan, individu memiliki perasaan dan niat yang baik pada orang lain tanpa rangsangan, individu yang kontrol emosinya baik memahami emosi orang lain , ini adalah fakta kalau empati memotivasi tindakan prososial seseorang yang dapat menimbulkan keperdulian yang tinggi, individu pada dewasa akhir lebih berempati dan berperilaku prososial dari orang dewasa awal (White, 2014).

Berdasar latar belakang tersebut peneliti dapat merumuskan masalah bagaimana hubungan dukungan sosial dengan perilaku prososial yang dimediasi oleh empati, tujuan dari penelitian ini adalah menguji aspek hubungan dukungan sosial dengan perilaku prososial dimediasi oleh empati.

Perilaku seseorang dapat berubah dalam proses penyesuaian diri terhadap lingkungannya. Perilaku individu masing-masing memiliki khas yang dapat membedakan tindakan dalam berintraksi antara individu satu dengan lainnya. Allport menyatakan kalau karakter dan sifat manusia bisa menyelaraskan perilaku seseorang, yang bisa menyebabkan seseorang melakukan pendekatan yang sama dalam kondisi berbeda. Orang yang mempunyai karakter ataupun sifat yang sama akan tetapi mereka tidak selalu menunjukkan cara yang sama.

Dalam kesehariannya empati sangat berperan penting dalam hubungan sosial dan interpersonal, dan dapat membagikan pengalaman, apa yang dibutuhkan, dan keinginannya dengan orang lain sehingga menyambungkan emosionalnya yang menyampaikan perilaku prososial dalam dirinya. Dalam hal ini kita dapat berintraksi dengan baik dengan diri sendiri dan orang lain, sehingga kita dapat melihat perspektif individu lain dan dapat membedakan emosi diri kita dengan orang lain (Riess, 2017).

Perilaku prososial dapat dipengaruhi oleh dukungan sosial dalam diri seseorang dan individu yang mempunyai empati yang tinggi meningkatkan perila$\mathrm{ku}$ prososial.

Hasil penelitian Guo (2017) menemukan bahwa dukungan sosial mendorong perilaku prososial pada individu, dimana kepercayaan mempunyai peran penting antara dukungan sosial dan perilaku sosial, subjek yang memberi dukungan sosial terlebih dulu harus dapat diterima dan dipercaya,sehingga akan memperkuat perilaku prososial karena Perilaku prosial harus didorong dan dilatih di lingkungan sekolah dan guru bisa membangun pengembangan moral pendidikan dan pembuat kebijakan harus membuat program yang tentunya mampu mendorong dan melatih perilaku prososial sesuai sasaran.

Dukungan sosial di lingkungan sekolah terkait dengan perilaku prososial. sekolah punya tanggung jawab untuk memperhatikan kesejateraan siswa, bagaimana tuntutan sekolah tidak membuatnya stres dan mengarahkan serta membimbing siswanya untuk berperilaku positif, sehingga siswa dapat beradaptasi dengan baik di lingkunganya (Plenty, Ostber dan Modin, 2015).

Eisenberg dan Musen (2009) menyatakan bahwa perilaku prososial meliputi beberapa bentuk tindakan seperti berbagi, kerjasama, menyumbang, menolong, kejujuran, dermawan, serta memperhatikan kesejahteraan dan hak orang lain. Indikator perilaku prososial, yaitu: berbagi, yakni memberikan waktu untuk seseorang menikmati milikinya, kerjasama , yaitu melakukan kegiatan bersama dengan orang lain untuk mencapai tujuan bersama, dalam berdiskusi membuat pertimbangan. Menyumbang adalah perbuatan yang memberikan secara materil kepada seseorang atau kelompok untuk kepentingan umum yang berdasarkan pada permintaan, kejadian dan kegiatan. Menolong yaitu membantu meringankan beban orang lain. Kejujuran yaitu tindakan dan ucapan yang sesuai dengan keadaan yang sebenarnya. Kedermawanan ialah memberikan sesuatuyang bisa berupa barang atau uang pada orang lain atas dasar kesadaran diri. Memperhatikan kesejahteraan dan hak orang lain adalah suatu tindakan untuk melakukan kepentingan pribadi yang berhubungan dengan orang lain tanpa melanggar. Bentuk dukungan seperti teori diatas sangat penting dan di butuhkan oleh siswa karena dukungan sosial mampu membuat seseorang nyaman.

Perilaku sosial tersebut harus dimiliki oleh siswa, pengajar, keluarga dan masyarakat, pemerintah berusaha keras mengarahkan remaja pada karakter dan pembentukan prososial, sehingga akan muncul generasi yang berkualitas karena semakin tinggi perilaku prososial individu semakin tinggi kesejateraan self-efficacy dan harga diri (Laiblea, Carlob, dan Roesch, 2011).

Penelitian Dar (2016) Peserta didik pada umumnya tidak mendapat informasi yang tepat dan memahami pentingnya berempati dan perilaku prososial dalam bersosialisasi, ini menunjukan antara empati dan perilaku sosial itu terkait erat dan dipengaruhi oleh pengalaman. Dilingkungan sekolah guru punya peran terhadap pengembangan empati dan perilaku prososial peserta didiknya..

Yoo, Feng dan Day, (2012) mengungkapkan bah- 
wa empati berhubungan dengan perilaku prososial individu, empati merupakan batasan dari remaja, apakah dia akan bertindak dan mengaktualisasikan perilaku prososial yang mereka miliki atau tidak. Awal penerapan empati dan memunculkan perilaku prososial diawali dari orang tua yang berperan dalam memberi wawasan tentang hal empati dan perilaku prososial.

Penelitian Eisenberg dan Fabes (1990) menjelaskan antara empati dan perilaku sosial ada hubungan, karena remaja yang memiliki empati bisa meningkatkan perilaku prososial. Seseorang yang berempati dapat memotivasi terbentuknya perilaku prososial,misal dengan menjadi relawan membantu orang lain tanpa mengharap imbalan dapat mengarah pada kebiasaan untuk perduli pada orang sekitar.

Berdasarkan uraian tersebut dapat disimpulkan individu yang mempunyai empati akan menunjukan perilaku prososial. Bila dalam diri sesorang itu tumbuh dan merasakan apa yang dirasakan orang lain maka akan terbentuk pribadi yang berkarakter perduli dengan orang lain dan tidak segan memberikan pertolongan pada siapa saja yang membutuhkan dalam kondisi apapun tanpa pamrih.

Dukungan sosial sangat penting dan dibutuhkan oleh siswa dalam kegiatan belajar di sekolah dari hasil penelitian Bakar dan Syahrudin, (2016). bahwa guru sangat harapkan siswa dalam mensosialisaikan pentingnya empati, selain itu ada teman sebaya dan orang tua. Hal itu penting karena anak perlu rasa aman dan nyaman dalam belajar sehingga kecil kemungkinan adanya penindasan karena merasa ada support dan secara psikologis tentunya tidak merasa cemas, malu, tapi merasa punya harga diri sehingga baik bagi psikologis siswa.

Penelitian (Park, 2015) mengatakan bahwa rendahnya tingkat empati sama rendahnya dengan dukungan sosial yang dapat menimbulkan stres, kondisi itu muncul karena tingakat empati yang rendah. Dukungan sosial harus berlanjut diberikan pada pelajar untuk meminimalisir tekanan dalam menjalani proses belajar dimana dukungan yang tepat sangat berdampak dalam menumbuhkan perilaku empati yaitu perilaku peduli pada orang lain.

Dari hasil uraian di atas, dapat disimpulkan dukungan sosial sangat dibutuhkan oleh siswa dalam menjalani proses belajar dengan harapan agar semua siswa belajar dilingkungan yang kondusif, kondisi itu tentunya karena peran serta keluarga guru,dan semua yang terlibat.terbentuknya empati harus terlatih dan melalui proses pembiasaan. Hal ini akan mengarah pada pemeliharaan atau peningkatan empati dalam jangka panjang.
Bahwa dukungan sosial, prososial dan empati saling berhubungan. Hal ini diperkuat penelitian Stuart, Hommond dan Bronell (2015). Perilaku prososial yaitu bentuk tindakan yang dilakukan dengan suka rela yang bertujuan agar bermanfaat bagi orang lain, perilaku ini pada masa remaja cenderung menurun karena pengaruh hormonal dan peristiwa fisiologis pubertas tapi seiring perkembangan akan membaik lagi, dimasa inilah dukungan sosial punya peran yang sangat penting.perilaku awal prososial individu adalah empati, faktanya perilaku itu terjadi yang pertama kali melalui reaksi menangis, dan muncul respon perilaku itu.

Dukungan sosial sangat terkait dengan perilaku prososial bahwa dukungan sosial punya efek yang kuat pada perilaku remaja dan sangat sulit bagi remaja berperilaku prososial ketika tidak ada kepedulian teman sebaya, keluarga atau komunitas yang mendukung betapa pentingnya prososial dan hal itu perlu dilatih (Lay, 2015)

\section{METODE \\ Desain Penelitian}

Pada penelitian ini desain yang dipakai adalah menggunakan pendekatan quantitative correlation resarch, pendekatan ini di gunakan sebagai penjelas hubungan dan penggaruh variabel dengan teknik uji statistik yang menggambarkan dan menggukur tingkat hubungan dengan variabel yang lainya (Cresweel, 2012). Pendekatan kuantitatif correlation untuk mengetahui kedekatan dengan variabel dan sejauh mana hubungan variabel dukungan sosial dengan perilaku prososial yang dimediasi oleh empati pada siswa .

\section{Subjek Penelitian}

Dalam penelitian ini, jumlah subjek 265 siswa, dari keseluruhan siswa yaitu 845 di SMP Negeri 14 Malang dan teknik yang digunakan untuk memilih subjek menggunakan purposive sampling dimana subjek yang dipilih sesuai dengan kriteria yang telah dipilih oleh peneliti, yaitu siswa yang aktif dikegiatan ekskul dan mengikuti diklat gabungan dari sekolah(Bacon, 2015).

\section{Instrumen Penelitian}

Perilaku prososial diukur dengan skala Prosocial Tendencies Measure-Revised (PTMR) oleh Carlo, Hausmann, Christiansen, dan Randall (2003) terdiri dari 15 item. Aspek perilaku prososial adalah menolong, jujur, dermawan, berbagi, kerjasama, dan membantu. Skala ini diadaptasi oleh Indah, (2018). Untuk setiap item prososial behavior, ditunjukkan pada 
subjek dengan format skala Liketr,ada empat pilihan jawaban ialah Sangat Setuju, Setuju , Tidak Setuju , Sangat Tidak Setuju, dengan Cronbach's alpha sebesar 0.853 setelah dilakukan uji validitas terdapat 6 item gugur dan 8 item dinyatakan valid (Caprara,2014)

Empati diukur oleh Emphaty Questionnaire berjumlah 15 item. Aspek-aspek empati yaitu kognitif dan afektif. Skala ini diadaptasi oleh Intan, (2018) Untuk setiap item Empathy Questionnaire, ditunjukkan peserta pada format skala Likert dengan pilihan empat jawaban yaitu, Sangat Setuju, Setuju , Tidak Setuju, Sangat Tidak Setuju,dengan Cronbach's Alpha sebesar 0.741 setelah dilakukan uji validitas semua item dinyatakan valid (Thorton,1995)

Dukungan sosial merupakan hubungan interpersonal yang didalamnya berisi bantuan yang melibatkan dukungan keluarga, teman sebaya dan guru, dukungan sosial sebagai variabel bebas yang diukur dengan menggunakan skala child and adolescent social support (CASS) disusun oleh Malecki, Demaray and Elliot, (2002). Skala ini diadaptasi oleh Dani, (2017) terdiri dari 31 item dengan pilihan sangat sering, sering, hampir tidak pernah dan tidak pernah, dengan Cronbach's alpha sebesar 0.928 setelah dilakukan uji validitas 29 item dinyatakan valid (White, 2009)

\section{Prosedur Penelitian}

Observasi dilakukan untuk mendapatkan gambaran awal dan data siswa, kemudian peneliti melanjutkan koordinasi dengan kepala sekolah guna meminta ijin untuk menyebarkan kuesioner dan melakukan wawancara, mempersiapkan kuesioner penelitian yang akan dipakai pada penelitian , lalu mengkondisikan siswa, memberikankan kuesioner penelitian kepada setiap siswa di dalam kelas lalu memberi petunjuk dan arahan cara pengisian pada kuesioner penelitian, setelah siswa faham dalam pengisian kuesioner tersebut, mempersilakan siswa mengisi kuesioner penelitian, setelah siswa selesai mengisi instrument, peneliti mengumpulkan data, setelah data terkumpul peneliti tidak langsung melakukan analisis data ,tapi harus melakukan uji validitas dan uji reliabilitas, setelah itu peneliti melakukan skoring dan terakhir baru melakukan analisis data.

\section{Analisis Data}

Dalam penelitian ini, uji hipotesa yang dilakukan dengan menggunakan model analisis data Process dari Hayes. yang tujuanya untuk menguji pengaruh variabel (M) dalam memediasi hubungan antara dukungan sosial (X) terhadap perilaku prososial (Y). (Hayes, 2014)

\section{HASIL DAN PEMBAHASAN}

Hasil

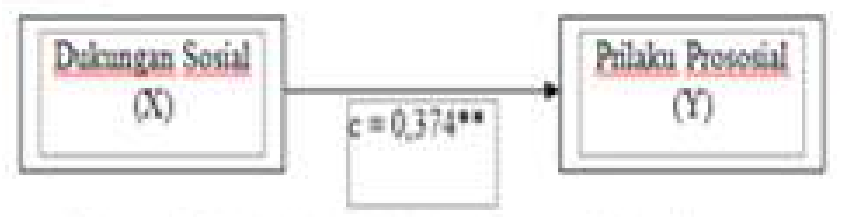

Gambar 1. Hasil Efek Total Hubungan Antara X dan Y

Hipotesis pertama (H1) dalam penelitian ini menyatakan ada hubungan dukungan sosial dengan perilaku prososial. Berdasarkan hasil analisis data yang telah dilakukan, diperoleh nilai koefisien efek total sebesar 0,374 dengan nilai $p=0,000(p<0,05)$ yang menunjukkan bahwa $\mathrm{H} 0$ ditolak dan $\mathrm{H} 1$ diterima. Dengan demikian dapat disimpulkan bahwa ada hubungan yang positif dan signifikan antara dukungan sosial dan perilaku prososial Siswa.

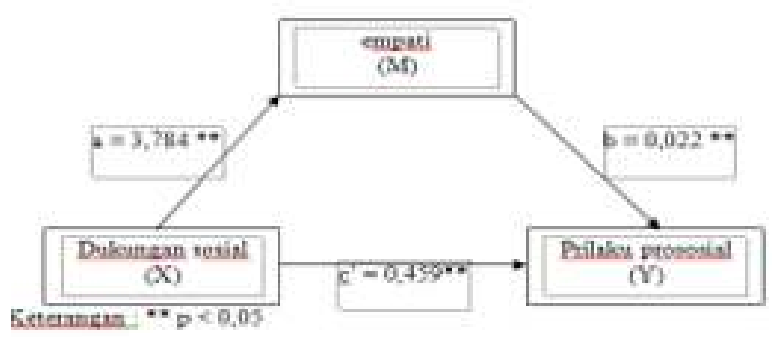

Gambar 2.Hasil Efek Tidak Langsung X | M - Y

Hipotesis kedua (H2a) pada penelitian ini menyatakan terdapat hubungan dukungan sosial dan empati siswa (jalur a). Berdasarkan hasil analisa data yang telah dilakukan, diperoleh nilai koefisien jalur a sebesar 3,784 dengan $p=0,000(p<0,05)$ yang berarti bahwa H2a diterima. Dengan demikian dapat disimpulkan bahwa ada hubungan yang positif yang signifikan antara dukungan sosial dengan empati siswa.

Hipotesis ketiga (H2b) dalam penelitian ini menyatakan ada hubungan empati dengan perilaku prososial (jalur b). Dari hasil analisis data yang telah dilakukan, diperoleh nilai koefisien jalur b sebesar 0,022 dengan $\mathrm{p}=0,000 \mathrm{p}<0,05$ yang menunjukkan bahwa H2b diterima, yaitu ada hubungan yang positif dan signifikan antara empati dengan perilaku sosial pada siswa.

Kemudian hipotesis keempat (H2c) dalam penelitian ini menyatakan "Ada hubungan dukungan sosial dengan perilaku prososial dengan empati siswa" (jalur c'). Berdasarkan hasil analisa data yang telah dilakukan, diperoleh nilai koefisien hubungan langsung jalur c' sebesar 0,459 dengan $\mathrm{p}=0,000(\mathrm{p}<0,005)$ yang menunjukkan bahwa H2c diterima. Dengan demikian dapat disimpulkan bahwa ada hubungan yang 
positif antara dukungan sosial dan perilaku prososial dengan empati siswa.dari analisis data Process Hayes yang sudah dilakukan nilai inderect effect tidak langsung adalah 0,085 berada diantara 0.144 sampai 0.04 karena 0 tidak termasuk dalam rentangan tersebut, maka dapat ditarik kesimpulan dalam penelitian ini menunjukan ada hubungan dukungan sosial dan perilaku sosial dimediasi oleh empati siswa. Mediasi yang terjadi adalah mediasi parsial karena empati tidak berperan penuh sebagai variabel mediasi terhadap perilaku prososial siswa.

\section{Pembahasan}

Penelitian dilakukan untuk mengetahui hubungan dukungan sosial dengan perilaku sosial dimediasi oleh empati pada siswa SMP Malang hasilnya menunjukkan ada hubungan dukungan sosial dengan perilaku prososial ,dukungan sosial dengan empati, empati terhadap perilaku sosial, serta empati bisa memperkuat hubungan antara dukungan sosial dengan perilaku prososial pada siswa.

Hipotesis pertama penelitian ini menunjukkan ada hubungan antara dukungan sosial dengan perilaku prososial. Remaja yang perilaku prosoialnya rendah sangat membutuhkan suport yang tinggi dari lingkungan ,bentuk suport dari orang tua bisa perhatian dan kasih sayang, dari guru nasehat, informasi dan pelatihan dari sekolah. semakin optimal dukungan sosial terhadap siswa, maka semakin tinggi perilaku prososial siswa.

Dukungan sosial dari teman sebaya yaitu motivasi, tempat curhat,dan penghibur. Teman adalah lingkup sosial yang sangat bermakna bagi remaja , sebagian besar waktu mereka habiskan sama teman dan bisa jadi mengalahkan porsi bersama keluarga karena kecenderungan remaja lebih dekat dengan teman dapat dipahami sebagai usaha menciptakan dunia yang bebas.

Dukungan sosial sangat berpengaruh pada psikologis dan fisik remaja, remaja yang dukungan sosialnya rendah akan mengalami stres dan remaja dengan dukungan sosial tinggi merasakan ada tempat untuk memberikan solusi masalah yang dialami dan menemukan titik terang masalahnya. Dukungan sosial mampu menjadi pelindung seseorang melawan efek negatif (Sarfino. 2002)

Perilaku prososial penting diterapkan agar individu mampu bekerjasama yang bisa berdampak pada konsentrasi akademik siswa, dalam lingkungan sekolah memberikan dukungan sosial penting pada pengembangan dalam pembentukan perilaku positif. Guru dapat menciptakan suasana lingkungan kelas untuk membangun hubungan yang positif den- gan siswa, menciptakan kelas yang penuh perhatian dan kedisiplinan dan komunikasi yang lebih efektif (Wentzel, 2015).

Perilaku prososial siswa dipengaruhi oleh bentuk perilaku positif, yang didukung dengan adanya guru dan teman sebaya yang memiliki potensi untuk pengembangan perilaku prososial. Dengan perilaku positif dapat menciptakan lingkungan kelas yang lebih baik secara emosional dengan menggunakan kognitif sosial yang lebih efektif untuk mengatur dirinya sendiri.

Perilaku prososial sangat penting dimiliki siswa sekolah menengah pertama yang sedang merasakan masa perkembangan sebagai remaja awal. Tugas pada siswa harus dicapai berkaitan dengan hubungan sosialnya. Dari perilaku prososial dapat mengantarkan para siswa untuk dapat mencapai tugas perkembangan dalam hidupnya dengan baik. (Wentzel, 1994).

Hipotesis kedua menunjukan ada hubungan dukungan sosial dan empati siswa. Empati mengacu pada kemampuan untuk merasakan apa yang orang lain rasakan. Sehingga dukungan sosial dari orang lain akan berdampak pada sikap empati dengan memiliki perasaan, kehangatan, kepedulian dan belas kasihan terhadap orang lain (Paleari, Tagliabue, \& Lanz, 2011).

Hubungan antara orang tua dan siswa dalam bersosialisasi diawal remaja sangat berpengaruh terhadap perilaku empati, remaja yang memiliki empati tinggi dapat mengembangkan perasaan bersalah yang ketika orang tua tidak mendukung dan dapat mengakibatkan depresi sehingga dukungan dari orang tua sangat penting pada remaja awal (Calandri, et al, 2019). Para siswa mampu menampilkan berbagai perilaku yang terkait pada sikap empati yang bagus. Salah satu cara mengukur siswa untuk melakukan empati dengan cara melihat respon mereka terhadap kesusahan yang dirasakan orang lain atau teman-temannya (McDonald, Messinger, 2015).

Hipotesis ketiga penelitian ini menunjukan ada hubungan empati dengan perilaku prososial. Siswa yang memiliki empati tinggi maka tinggi pula perilaku prososialnya, siswa yang berempati punya motivasi untuk memberikan tindakan saling tolong menolong terhadap temannya dan perasaan prihatin terhadap orang lain (Graaff, et al, 2017). Pada penelitian lain menemukan bahwa individu yang rentang mengalami tekanan pada pribadinya mengakibatkan lebih rendah empati nya pada orang lain (Barr, 2007)

Empati menekankan tingkat individu untuk merespons individu lainnya, dengan adanya pertimbangan aspek kognitif dan afektif, pentingnya kapasitas agar dapat membedakan antara diri sendiri dan individu lainnya. , dengan mendukung keterampilan ber- 
orientasi dengan kehangatan pada hubungan antar pribadi. (Garaigordobil, 2009).

Hipotesis keempat penelitian ini menunjukan ada hubungan dukungan sosial dengan perilaku prososial dimediasi oleh empati, antara empati terhadap perilaku prososial menunjukan adanya kontribusi,. Apabila individu memiliki empati yang semakin tinggi maka semakin tinggi pula perilaku prososial yang dimiliki individu, begitu juga empati dan prososial pada siswa (Pradayana \& Lestari, 2016). Empati yang dimiliki oleh setiap individu itu sangat berbeda-beda, termasuk pada siswa yang sedang pada masa perkembangan, siswa yang memiliki empati tinggi akan memiliki prososial yang tinggi juga. Hal itu dikarenakan empati merupakan aktivitas dalam memahami dan ikut merasakan hal apa yang dirasakan oleh individu lain, sehingga empati mengarahkan seorang siswa agar berperilaku prososial (Purnamasari, 2018).

\section{KESIMPULAN DAN SARAN Kesimpulan}

Dari hasil penelitian ini maka dapat disimpulkan bahwa dukungan sosial memiliki hubungan terhadap perilaku prososial melalui empati, jadi terbentuknya perilaku sosial karena empati. Dukungan sosial memberikan kontribusi positif pada perilaku prososial yang dimediasi oleh empati, siswa yang mendapatkan dukungan sosial yang baik akan lebih berempati dan menunjukan perilaku prososial .

\section{Saran}

Berdasarkan hasil penelitian ini bagi siswa agar bisa menerapkan perilaku prososial dalam lingkungan sekolah maupun masyarakat. Untuk teman diharapkan mampu menjadi tutor sebaya dalam menjalin pertemanan dengan didasari empati, karena teman sangat kuat pengaruhnya dan mudah didengar pendapatnya, bebas curhat, nyaman karena usia dan hoby yang sama.

Untuk orang tua diharapkan lebih fokus memberi dukungan, bimbingan ,perhatian, arahan yang baik pada siswa agar tercipta perilaku prososial, karena orang tua memiliki peranan penting dalam tumbuh kembang anak.

Masukan bagi lingkungan pendidikan dan guru, khususnya guru bimbingan konseling (BK) untuk lebih memperhatikan karakter peserta didik,mengadakan outdoor learning, pelatihan dan diklat yang bermuatan karakter secara rutin persemester, karena melalui sekolah yang merupakan wadah pembelajaran untuk menumbuhkan empati sehingga muncul perilaku prososial dengan dukungan sosial dari guru dan pihak sekolah agar tercipta lingkungan belajar yang kondusif.

Pada peneliti selanjutnya diharapkan hasil penelitian ini dapat memberikan tambahan wawasan dan pengetahuan tentang konsep dukungan sosial, prilaku prososial dan empati siswa di lingkungan pendidikan. juga dapat melengkapi referensi tentang hubungan variabel mediasi yaitu empati dalam mempengaruhi hubungan dukungan sosial dan perilaku prososial siswa yang belum di kaji pada penelitian sebelumnya. Mengkaji perilaku prososial siswa dari variabel lain, pemakaian alat ukur yang lebih baik dan dapat memperluas subjek penelitian misalnya perbandingan pada subjek siswa sekolah swasta dan sekolah negeri .

\section{DAFTAR PUSTAKA}

Afolobi, O. A. (2014). Psychoasocial predictor of prosocial behavior among a sample of nigeria undergradaute. European Scientific Journal, 10(2), 187-1881.

Bacon, S. J. (2015). Internatonal to kuantitative methods. Grauate School The University of Hong Kong. Retrieved from https://org.10.13140/2.1.4466.3040

Bakar, Z. A., Syahrudin, M. (2016). The importance of social support to bullying victims: a case study in indonesia. University of Teknologi Malaysia Skudai Johor Malaysia, 1-9.

Barr, J. J. (2007). Adolescent empathy and prosocial behavior in the multidimensional context of school culture. The Journal of Genetic Psychology, 168(3), 231-250.

Batson, C. D. (2010). Empathy-induced alturistic motivation. Inagural H Erzliya Symposium "Prosocial Motives Emotions Anf Behavior, 1-22.

Calandri, E., Graziano, F., Testa, S., Cattelino, E., Begotti, E. (2019). Empathy and depression among early adolescents: the moderating role of parental support. Journal US National Library of Medicine National Institutes of Health, 10(1447), 1-5. https://doi.org/doi: 10.3389/fpsyg.2019.01447

Caprara, G. V., Kanacri, B. P. L., Gerbino, M. Zuffiano, A., Alessandri, G., Vecchio, G., Caprara, E., Pastorelli, C., Bridgall, B. (2014). Positive effects of promoting prosocial behavior in early adolescence: evidence from a school-based intervention. International Journal of Behavioral Developement, 1(2), 1-11. https://doi.org/10.1177/0165025414531464

Carlo, G., Hausman., A, Christiansen, S. B. (2003). Cognitive and behavioral correlates of a measure of prosocial tendencies of adolescents. Journal of Early Adolescence, 23, 107-134

Cirik, L. (2015). Relationships between social support motivation and science achievement: sructural eguation modeling. Anthropologist, 20(1,2), 232- 


\section{2.}

Cresweel, J. W. (2012). Research design pendekatan kualitatif kuantitatif dan mixed. Yogyakarta: Pustaka Pelajar.

Dani, S. (2017). Pengaruh dukungan sosial dan spiritualitas terhadap resiliensi survivor bencana alam. Universitas Muhammadiyah Malang.

Dar, F. R. (2016). Empatheic and pro-social awareness in primary school students. Universal Journal of Educational Research, 4(10), 2406-2414.

Dayaksini, T., H. (2009). Psikologi sosial. Malang: Umm Press.

Eisenberg, N., Fabes, R. A. (1990). Empathy, conseptualization, measurement, and relation to prosocial behavior. Motivation and Emotional, 14(2), 131-146.

Garaigordobil, M. (2009). A comparative analysis of empathy in childhood and adolescence: gender differences and associated socio-emotional variables. International Journal of Psychology and Psychological Therapy, 9(2), 217-235.

George, B. C. (2006). Gordon allport personality theories. Psychology Departemen Shippensburg University.

Gordon, G., Delton, S., Kolbert. J. B., Kanyongo, G. Y., Crothers, L. M. (2004). Proactive and reactive aggresion and cognitive and affective empathy among students in minddle childhood. International Journal of School and Cognitive Psychology. https:// doi.org/http://dx.org/10172/1234-3425.100105

Graaff, J. P.D., Carlo, G., Crocett, E., Koot, H. M., Branje, S. (2017). Prosocial behavior in adolescence: gender differences in development and links with empathy. Journal Youth Adolescence, 47(6), 1-5. https://doi.org/DOI 10.1007/s10964-017-0786-1

Guo, Y. (2017). The influence of social support on the prosocial behaviour of college students: the mediating effect based on interpersonal trust. English Language Teaching, 10(12), 1916-4750. Retrieved from http://doi.org/10.5539/elt.v10n12p158

Hayes, A. F. (2014). Statistical mediation analysis with a multicategorical independent variable. British Journal of Mathematical and Statistical Psychology, 67(2), 451-470.

Hoffman. (200). Empathy and Moral Development Implications For Caring and Justice. Cambridge Universitas Press.

Indah, P. (2018). Hubungan kemampuan mengatasi krisis paruh baya dan dukungan sosial dengan kebermaknaan hidup pada dewasa madya yang bekerja. Univeristas Muhammadiyah Malang.

Intan, R. (2018). Hubungan empati dan perilaku prososial: dimoderasi oleh kepribadian agreeableness pada mahasiswa keperawatan stikes yarsi mataram. Universitas Muhammadiyah Malang.

Kartono, K. (2003). Kamus psikologi. Bandung: Pioner Jaya.

Krevan \& Gibbs. (1996). Empathetic and prosocial awareness in primary school students a cas study. Journal of Educational Research, 4(10), 24062414.

Laiblea, D. J., Carlob, G., Roesch, C. S. (2011). Pathways to self-esteem in late adolescence: the role of parent and peer attachment,empathy,and social behaviours. Journal of Adolescence, 27, 703-716. https://doi.org/doi:10.1016/j.Adolescence.05.005

Lay, . Y. F. H., Siu, A. M. H., Shek, D. T. L. (2015). Individual and sosial prediktor of prosocial behavour among chinese adoloscen hongkong. Journal List Front Prediator, 3-39.

McDonald, N. M., dan Messinger, D. S. (2015). The development of empathy: how, when, and why. Journal University of Miami Department of Psychology, 55(7), 1-36.

Paleari, F. G., Tagliabue, S., Lanz, M. (2011). Empathic perspective taking in family relationships: a social relations analysis. Journal University of Bergamo Italy, 185(202), 186-189.

Park, K. H. (2015). The relationship between empathy stress and social support between people. Published Online. Retrieved from 10.5117/ijme.5506. od44

Plenty, S., Ostberg, V., Modin, B. (2015). The role of psychosocial school conditions in adolescent prosocial behavio. School Psychology International, 36(3), 283-300.

Pradnyana, A. A. G. P. S., Lestari, M. D. (2016). Peran perilaku prososial, efikasi diri dan empati pada pegawai badan penanggulangan bencana daerah (BPBD) di bali. Jurnal Psikologi Udayana, 3(3), 491-498.

Purnamasari., I. (2018). Kontribusi empati dan dukungan sosial teman sebaya terhadap perila$\mathrm{ku}$ prososial siswa di SMP. Indonesian Journal of Guidance and Counseling: Theory and Application, $7(2), 20-26$.

Riess, H. (2017). The sciences of empathy. Journal of Patient Experience, 4(2), 74-77. https:/doi. org/10.1177/2374373517699267

Rook, K. S. (1990). Parallels in the study of social support and social strain. Journal of Social and C;inical Psyghology, 19(50), 765-767.

Sears, D. O., Fredman, J. L., Peplau, L. A. (1991). Psikologi sosial. Jakarta: Erlangga.

Sarafino. (2002). Health psychology :Biopsychososial intraction fifth edition. Valente, F. (2016). Em- 
pathy and communication: A model of empathy devepment. Journal of new meda and mass communiction.

Taufik. (2013). Empati pendekatan psikologi sosial. Jakarta: PT Raja Grafindo Persada.

Thorton, D. (1995). Empathy questionnaire. Personality and Individual Differences, 19(50), 765-767.

Valente, F. (2016). Empathy and communication: A model of empathy devepment. Journal of new meda and mass communiction.

Wentzel, K. (2015). Prosocial behaviour and schooling. Encyclopedia On Early Childhood Development, $1-5$.

Wentzel, K. R. (1994). Relations of social goal pursuit to social acceptance, classroom behavior, and perceived social support. APA PsycNET, 86(2), 173-182.

White, B. A. (2014). Who cares when nobody is watching? psychopathic traits and empathi in prosocial behaviour. Journal and Individual Differences, 56(1), 116-121.

White, T. N. (2009). The influence of social support from parent, classmate and teacher on early adolescents'mental health. Graduate Theses and Dissertasional. Retrieved from http://scholarcommons.usf.udu.etd/82

Yang, J. (2006). Reseach on prosocial value orientation and prosocial behavior of college. Students Master's Thesis at Huazhong University of Science and Technology.

Yasin, S, A. C. (2010). The relationship between soscial suppord and psycological problem among students. Centre for Promating Edeas, 1-3.

Yoo, H., Feng, X., dan Day, R. D. (2012). Adolescent' empathy and prosocial behavior in the family context; a longitudinal study. Springer Science Business Media. Retrieved from 10.1007/s 10964-0129900-6 